\title{
Use of the TSPY gene for sexing cattle
}

\author{
Daniela Cristina Lemos, Álvaro Fabrício Lopes Rios, Lisandra Cristina Caetano, Raysildo Barbosa Lôbo, \\ Reginaldo Aparecido Vila, Lúcia Martelli, Paula Lumy Takeuchi and Ester Silveira Ramos \\ Universidade de São Paulo, Faculdade de Medicina de Ribeirão Preto, Departamento de Genética, \\ Ribeirão Preto, SP, Brazil.
}

\begin{abstract}
The $Y$-encoded, testis-specific protein (TSPY) is a Y-specific gene. The copy numbers of TSPY range from 20 to 60 in men and up to 200 in bulls. In this study, we examined the possibility of using the TSPY gene to sex cattle. DNA from blood samples of 100 Nelore cattle (50 males and 50 females) from the Nelore Cattle Breeding Program (PMGRN) was screened for TSPY by PCR using TSPY-specific primers. The assay was highly specific since all male samples were TSPY-positive and all female samples were negative. Positive results were also obtained at low DNA concentrations (less than $1 \rho \mathrm{g} / \mu \mathrm{L}$ ). These results showed that TSPY was a good male-specific marker, the usefulness of which was enhanced by the high copy number of the gene. This is the first report to demonstrate the applicability of TSPY for sexing cattle.
\end{abstract}

Key words: bovine, cattle, PCR, sexing, TSPY.

Received: December 3, 2003; Accepted: August 16, 2004.

Determining the sex of beef by reliable molecular methods is an important measure to ensure the correct allocation of export refunds, which are considerably higher for male beef (Zeleny et al., 2002). However, although a number of assays have been used to determine the sex of bovine embryos, they are not widely used because of their lack of accuracy and speed (Bredbacka et al., 1995).

A more practical and efficient approach for determining the sex of cattle is to amplify sequences of the Y chromosome by the polymerase chain reaction (PCR) using sequence-specific primers (Alves et al., 2003). The advent of PCR has increased the interest in sexing cattle, and the potential usefulness of this technique has been demonstrated (Bredbacka et al., 1995). Using this approach, male and female beef has been identified by amplifying the $S R Y$, amelogenin and $Z F Y$ genes, as well as other Y-specific sequences (Levinson et al., 1992; Chong et al., 1993; Cui et al., 1994). Homologous but non-identical copies of the amelogenin and $Z F Y$ genes are also located on the $\mathrm{X}$ chromosome and can serve as internal controls for successful amplification using the same sets of primers (Pierce et al., 2000).

The Y-encoded, testis-specific protein TSPY (Arnemann et al., 1991) is a Y-specific gene (Affara et al.,

Send correspondence to Ester Silveira Ramos. Universidade de São Paulo, Faculdade de Medicina de Ribeirão Preto, Departamento de Genética, Av. Bandeirantes 3900, 14049-900 Ribeirão Preto, SP, Brazil. E-mail: esramos@rge.fmrp.usp.br.
1996). TSPY homologs exist in several mammalian species, including humans, horses and cattle (Jakubiczka et al., 1993; Schempp et al., 1995; Vogel et al., 1997). The TSPY genes are arranged in clusters on the $\mathrm{Y}$ chromosome of many mammalian species and form part of a superfamily, TTSN (TSPY-TSPYL-SET-NAP1L1 genes), with highly conserved autosomal representatives (Vogel and Schmidtke, 1998). In humans and cattle, TSPY expression is apparently restricted to male germ cells and their precursors, and begins during fetal development. The cellular site of expression suggests a function in spermatogonial proliferation (Vogel et al., 1997).

In this study, DNA from blood samples of male $(\mathrm{n}=$ $50)$ and female $(n=50)$ cattle was screened for the presence of TSPY using PCR. All of the animals used belonged to the Nelore Cattle Breeding Program (PMGRN). Genomic DNA was extracted from peripheral blood leucocytes using standard methods (Olerup and Zetterquist, 1992), and the sex was confirmed by PCR. The TSPY-specific primer sequences were: 5' CCCGCACCTTCCAAGTTGTG 3' and 5' AACCTCCACCTCCTCCACGATG 3'. These primers amplified a 260-bp segment of TSPY and were based on sequences reported by Jakubiczka et al. (1993) (GenBank accession X74028 - B. taurus TSPY gene). The DNA sequence was amplified by an initial denaturation step at $94{ }^{\circ} \mathrm{C}$ for $5 \mathrm{~min}$, followed by 35 cycles of denaturation at $94{ }^{\circ} \mathrm{C}$ for $45 \mathrm{~s}$, annealing at $64{ }^{\circ} \mathrm{C}$ for $45 \mathrm{~s}$ and synthesis at $72{ }^{\circ} \mathrm{C}$ for $45 \mathrm{~s}$. An additional extension time of $10 \mathrm{~min}$ was 
included at the end of the final cycle. The PCR was done using a TGradient thermocycler (Whatman-Biometra). The reaction final volume of $25 \mu \mathrm{L}$ contained $100 \mathrm{ng}$ of DNA, $10 \mathrm{mM}$ Tris- $\mathrm{HCl}$ ( $\mathrm{pH} 8.4), 25 \mathrm{mM} \mathrm{KCl}, 1.5 \mathrm{mM} \mathrm{MgCl}_{2}$, $100 \mu \mathrm{M}$ of each dNTP, 1.0 U Taq polymerase (GibcoBRL), and $0.05 \mathrm{mM}$ of Y-specific primers. The amplification products were analyzed by electrophoresis in $2 \%$ agarose gels stained with ethidium bromide. The sensitivity of the PCR was investigated using different concentrations of male DNA, with the desired amount of DNA contained in $1 \mu \mathrm{L}$ of each dilution (Table 1).

The PCR using TSPY-specific primers was specific since all of the male samples were TSPY-positive and all of

Table 1 - DNA dilutions and concentrations used to determine the sensitivity of the PCR.

\begin{tabular}{lcc}
\hline Dilution & Initial DNA concentration & $\begin{array}{c}\text { DNA concentration in PCR } \\
\text { mix }(25 \mu \mathrm{L})\end{array}$ \\
\hline 1 & $0.1 \mu \mathrm{g} / \mu \mathrm{L}-100 \mathrm{vg} / \mu \mathrm{L}$ & $4 \eta \mathrm{g} / \mu \mathrm{L}$ \\
2 & $10 \eta \mathrm{g} / \mu \mathrm{L}$ & $400 \rho g / \mu \mathrm{L}$ \\
3 & $1 \eta \mathrm{g} / \mu \mathrm{L}$ & $40 \rho g / \mu \mathrm{L}$ \\
4 & $100 \rho g / \mu \mathrm{L}$ & $4 \rho g / \mu \mathrm{L}$ \\
5 & $10 \rho g / \mu \mathrm{L}$ & $0.4 \rho g / \mu \mathrm{L}$ \\
6 & $1 \rho g / \mu \mathrm{L}$ & $0.04 \rho g / \mu \mathrm{L}$ \\
\hline
\end{tabular}

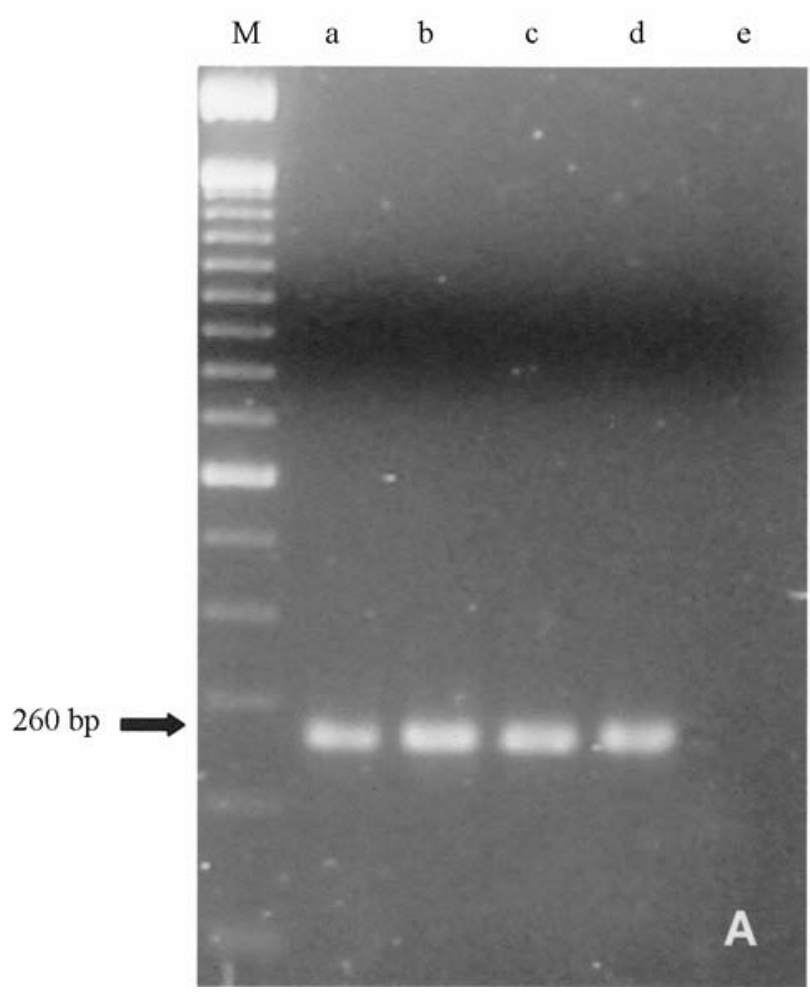

the female samples were negative. All of the DNA dilutions prepared from male samples gave a positive result (Figure 1).

PCR is a rapid, easy procedure for large scale sexing, and primers derived from many $\mathrm{Y}$-specific sequences have been used to screen blood, meat and blastomere samples (Alves et al., 2003; Zeleny et al., 2002). Manz et al. (1998) demonstrated the potential usefulness of TSPY for sex diagnosis in equine preimplantation, and Pierce et al. (2000) described a highly accurate method for determining the sex of human embryos by real-time PCR of this same gene.

Bovine TSPY consists of seven exons that are separated by six introns. The genomic organization of the bovine and human genes is highly conserved and both are part of a Y-specific gene family (Vogel et al., 1997). The copy numbers range from 20 to 60 in men and up to 200 in bulls (Manz et al., 1998).

Park et al. (2001) optimized consecutive and multiplex PCR using whole blood from males and different DNA concentrations (minimum $=5 \rho \mathrm{g}$ ). These authors subsequently successfully applied the method to groups of 1,2 , 4 and 8 blastomeres dissociated from bovine embryos. The sexing efficiency was $92.1,94.3,96.3$ and $100 \%$, respectively.

In conclusion, primers derived from a TSPY sequence allowed the accurate detection of DNA in bovine blood samples. The positive results obtained at low DNA concen-

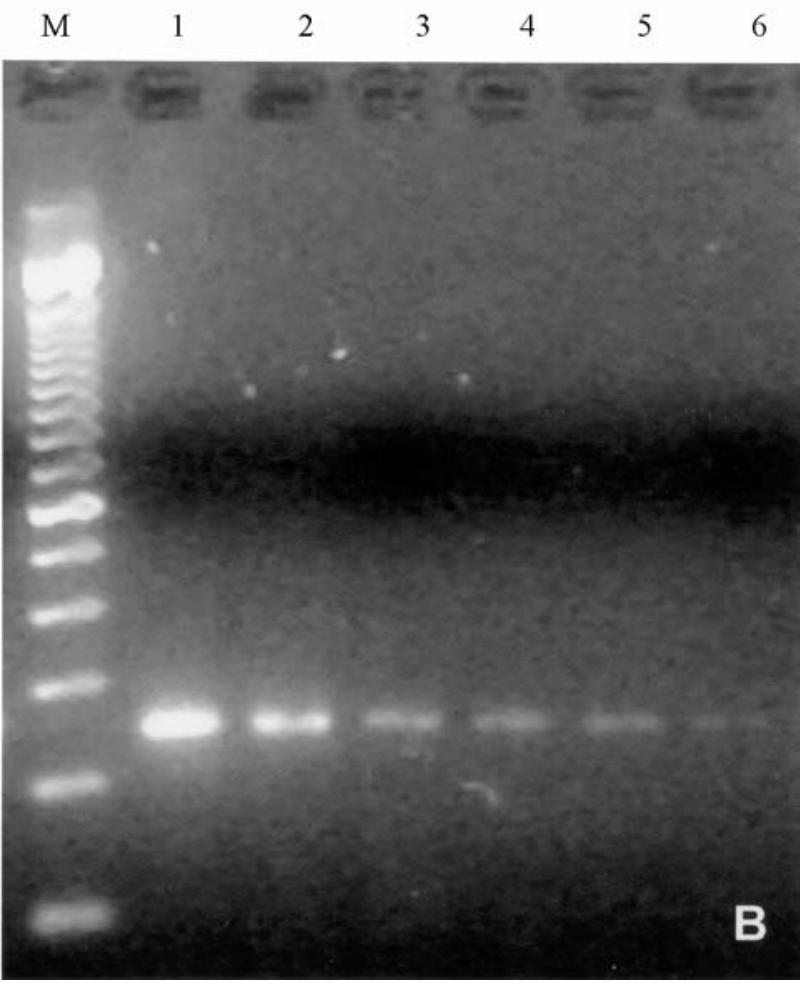

Figure 1 - (A) PCR amplification patterns of bovine DNA using TSPY-specific primers. The solid arrowhead indicates the 260 bp Y-specific sequence present in Nelore males (a, b, c, d). This sequence is absent in Nelore females (lane e). M indicates molecular weight marker (100 bp ladder). (B) PCR amplification patterns for various dilutions of DNA from males. The lane numbering $(1,2,3,4,5$, and 6$)$ corresponds to the dilutions described in Table 1 . 
trations probably reflected the elevated copy number for this gene and showed that TSPY is potentially useful for sexing cattle, and possibly also for screening bovine embryos. To our knowledge, this is the first study to demonstrate the usefulness of the TSPY gene for sexing cattle.

\section{Acknowledgments}

This work was supported by ANCP, CNPq (grant no. 141468/2000-9), FAPESP, FAEPA and PRONEX (grant no. 66.1036/1998-7).

\section{References}

Affara N, Bishop C, Brown W, Cooke H, Davey P, Ellis N, Graves Jm, Jones M, Mitchell M, Rappold G, Tyler-Smith C, Yen P and Lau Y-FC (1996) Report of the second international workshop on Y chromosome mapping 1995. Cytogenet Cell Genet 73:33-76.

Alves BCA, Hossepian De Lima VFM, Teixeira CM and Moreira-Filho CA (2003) Use of primers derived from a new sequence of the bovine $\mathrm{Y}$ chromosome for sexing Bos taurus and Bos indicus embryos. Theriogenology 59:1415-1419.

Arnemann J, Jakubiczka S, Thüring S and Schmidtke J (1991) Cloning and sequence analysis of a human Y-chromosomederived, testicular cDNA, TSPY. Genomics 11:108-114.

Bredbacka P, Kankaanpää A and Peippo J (1995) PCR-sexing of bovine embryos: A simplified protocol. Theriogenology 44:167-176.

Chong SS, Kristjansson K, Cota J, Handyside AH and Hughes MR (1993) Preimplantation prevention of X-linked disease: Reliable and rapid sex determination of single human cells by restriction analysis of simultaneously amplified ZFX and ZFY sequences. Hum Mol Genet 2:1187-1191.

Cui KH, Warnes GM, Jeffrey R and Matthews CD (1994) Sex determination of preimplantation embryos by human testisdetermining-gene amplification. Lancet 343:79-82.
Jakubiczka S, Schnieders F and Schmidtke J (1993) A bovine homologue of the human TSPY gene. Genomics 17:732-735.

Levinson G, Fields RA, Harton GL, Palmer FT, Maddalena A, Fugger EF and Schulman JD (1992) Reliable gender screening for human preimplantation embryos, using multiple DNA target-sequences. Hum Reprod 7:1304-1313.

Manz E, Vogel T, Glatzel P and Schmidtke J (1998) Identification of an equine Y chromosome specific gene locus (eTSPY) with potential in preimplantation sex diagnosis. Theriogenology 49:364.

Olerup O and Zetterquist H (1992) HLA-DR typing by PCR amplification with sequence-specific primers (PCR-SSP) in 2 hours: An alternative to serological DR typing in clinical practice including donor-recipient matching in cadaveric transplantation. Tissue Antigens 39:225-235.

Park JH, Lee JH, Choi KM, Joung SY, Kim JY, Chung GM, Jin DI and Im KS (2001) Rapid sexing of preimplantation bovine embryo using consecutive and multiplex polymerase chain reaction (PCR) with biopsied single blastomere. Theriogenology 55:1843-1853.

Pierce KE, Rice JE, Aquiles Sanchez J, Brenner C and Wangh LJ (2000) Real-time PCR using molecular beacons for accurate detection of the $\mathrm{Y}$ chromosome in single human blastomeres. Mol Hum Reprod 6:1155-1164.

Schempp W, Binkele A, Arnemann J, Glaser B, Ma K, Taylor K, Toder R, Wolfe J and Chandley AC (1995) Comparative mapping of YRRM- and TSPY-related cosmids in man and hominoid apes. Chromosome Res 3:227-234.

Vogel T, Dechend F, Manz E, Jung C, Jakubiczka S, Fehr S, Schmidtke J and Schnieders F (1997) Organization and expression of bovine TSPY. Mamm Genome 8:491-496.

Vogel T and Schmidtke J (1998) Structure and function of TSPY, the Y-chromosome gene coding for the "testis-specific protein". Cytogenet Cell Genet 80:209-213.

Zeleny R, Bernreuther A, Schimmel H and Pauwels J (2002) Evaluation of PCR-based beef sexing methods. J Agric Food Chem 50:4169-4175.

Associate Editor: Pedro Franklin Barbosa 